\title{
Analysis of traffic capacity and design for the reconstruction of a large roundabout in the city of Zagreb
}

\author{
I. Legac, H. Pilko \& D. Brčić \\ Faculty of Transport and Traffic Sciences, University of Zagreb, Croatia
}

\begin{abstract}
The paper deals with the issues regarding the need for the reconstruction of a large three-lane roundabout with the reached AADT traffic of over 90,000 [veh./day] and intense tram traffic at the level below the road surface. Since the existing roundabout dates back to 1985, the design solution with tangential merging of three-lane approaches provides an additional cause and reason for reduced capacity and safety component of the entire intersection. In the new urban, and commercial and spatial surrounding, with the help of radical reconstruction it is necessary to achieve a modern design solution, for which purpose extensive interdisciplinary research was conducted. Common multidisciplinary methods and criteria are presented in six proposed design solutions, with particular focus on the capacitive-safety and design elements and their interrelations.

Keywords: large three-lane roundabout, reconstruction, capacity-safety-design, multi-disciplinary analysis, investment decision.
\end{abstract}

\section{Introduction}

The paper presents the reconstruction analysis of the Jadranska Avenue and Dubrovnik Avenue for the purpose of which three conceptual solutions have been used (N. Šubić, AKING/GF and M. Vukušić). The objective of the performed analyses is to find the optimal traffic, urban, and technical solution, using multi-criteria procedures and decision-making. The reasons for the design are presented as well as the current traffic condition on the location of this roundabout, and all the problems regarding the capacity and safety of traffic. The presented data and the description of the traffic and safety problems show the 
reasons why the municipal administration wants to bring the roundabout into the condition of sufficient capacity and safety of traffic participants. The evaluation of the proposed/variant solutions should be carried out according to one of the advanced and generally acknowledged methods. For the multi-criteria decisionmaking the so-called AHP (Analytic Hierarchy Process) method has been selected because the concrete case refers to a large number of criteria and decision-makers. The solving of complex decision-making problems using this method is based on a number of smaller and soluble rankings per component criteria (objective - criteria - alternatives). In the solving of the multi-criteria analysis the Expert Choice software package will be used.

\section{Current state}

The Jadranska Avenue - Remetinečka Avenue - Avenue Dubrovnik - Jadranski Bridge roundabout is located at the south-western entry into the city of Zagreb, opened to traffic on 9 September 1985. Before reconstruction it was designed as a signalized at-grade intersection, with grade-separated pedestrian traffic and with no tram traffic. Fast urbanisation, insufficient number of bridges spanning the Sava river, and increased traffic load of the south-western entry into the city influenced the increased traffic load of the traffic network. With the aim of increasing the traffic safety, increasing the capacity and introducing the tram traffic to the traffic junction, a roundabout was constructed as the most suitable solution at the upper level, and a passage for the pedestrians (pedestrian paths) and trams with relief tracks at the lower level.

\subsection{Design and traffic flows}

The respective traffic complex has the form of a big intersection with a circular flow with four approaches: Jadranska Avenue, Avenue Dubrovnik, Jadranski Bridge and Remetinečka Road (Figure 1). The intersection is located in the

a)

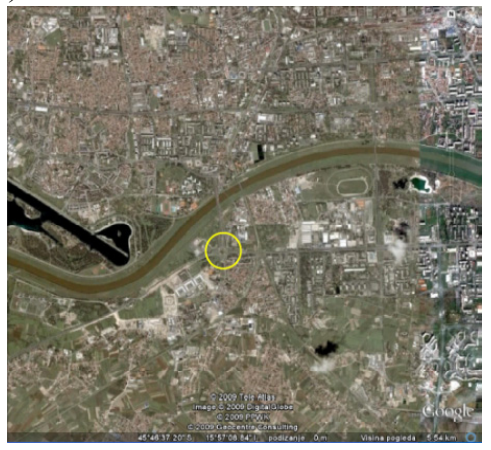

b)

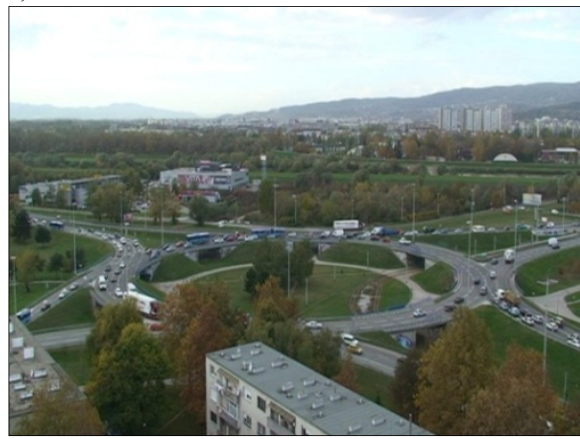

Figure 1: $\quad$ Roundabout Jadranska Avenue - Avenue Dubrovnik; a) disposition in urban network; b) photo viewed from the south-east $[1,2]$. 
flatland without any major limitations, whereas the approach routes are at longitudinal gradients of $1 \%$ to $3 \%$. The external diameter of the roundabout $\left(D_{v}\right)$ is 148 metres, whereas the internal diameter $\left(D_{u}\right)$ is 124 metres. The carriageway is divided into three lanes each four metres wide, and the approaches are designed with three lanes, but 3.5 metres wide. The approaches merge into the roundabout with a radius $(\mathrm{R})$ of 80 metres except for the northern approach, which merges with a radius (R) of 200 metres. The circular carriageway has a gradient of about $2 \%$ towards the centre because of the rainfall drainage [1-3].

1

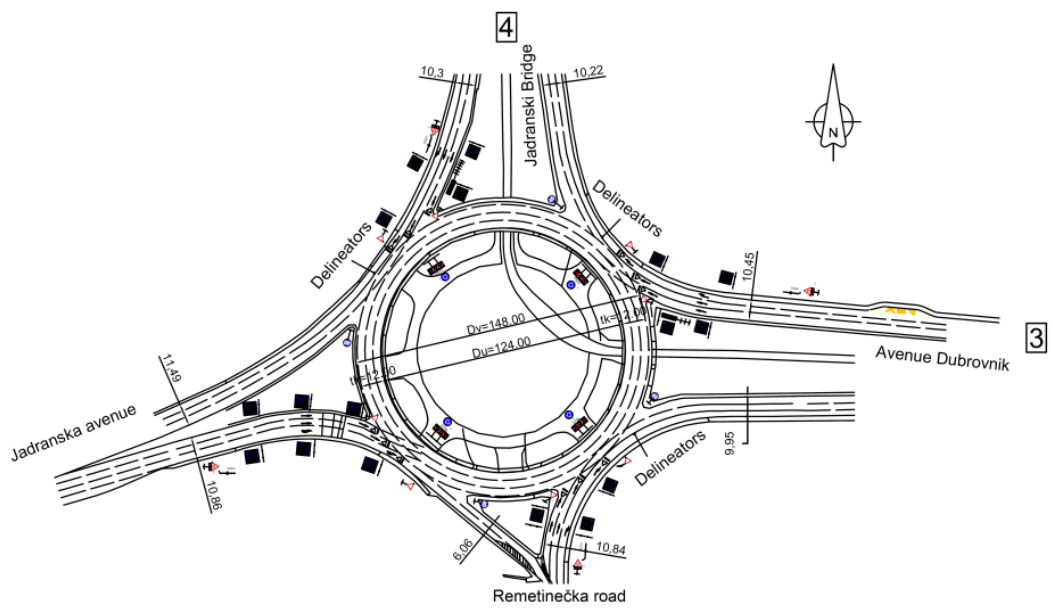

2

Figure 2: $\quad$ Layout design elements of the current intersection [2].

In order to present the traffic load of the intersection, the latest measurable data collected on 24 October 2008 (Table 1) were used. The traffic load of the intersection amounted to $\mathrm{Q}_{\mathrm{k}}=99,023$ [veh/day] registering a more pronounced load on all the approaches except on approach 2 [4].

Table 1: $\quad$ AADT at Jadranska avenue - avenue Dubrovnik roundabout [4].

\begin{tabular}{|c|c|c|c|c|}
\hline \multicolumn{5}{|c|}{ AADT - 24.10.2008. } \\
\hline \multirow{4}{*}{ APPROACH } & Right & Straight & Left & $\Sigma$ \\
\cline { 2 - 5 } & 11 & 11,060 & 12,817 & 23,888 \\
\hline 1. Jadranska Avenue & 3,928 & 7,126 & 20 & 11,074 \\
\hline 2. Remetinečka Road & 24,647 & 8,344 & 1,513 & 34,504 \\
\hline 3. Avenue Dubrovnik & 12,975 & 4,575 & 12,007 & 29,557 \\
\hline 4. Jadranski Bridge & TOTAL & $\mathbf{9 9 , 0 2 3}$ \\
\hline \multicolumn{5}{|c|}{}
\end{tabular}




\subsection{Traffic safety}

The analysis and the checking of the level of traffic safety was performed on the basis of the video recording, and on the analysis of the approach speeds, visibility and equipment of the intersection, and the results of this research have been published in the earlier communications $[1-3,5]$. However, because of the purpose and the objective of this work, the collision diagram has been presented (Figure 3), and the official data of the traffic police for the period from 2001 to 2010 have been processed and analysed [6]. Table 2 shows the total number of accidents per years of occurrence, per number and types of accidents, and per number of the injured per years and types of accidents. The observed period shows that the most usual types of accidents are:

- rear-end collisions accounting for as many as 1,185 accidents, or $60.46 \%$ out of the total number of accidents in which 111 persons were injured or $59.04 \%$ of the total number of the injured;

- failure to yield at entry (entering-circulating) accounting for 506 incidents or $25.82 \%$, with 39 injured or $20.75 \%$ of the total number of the injured.

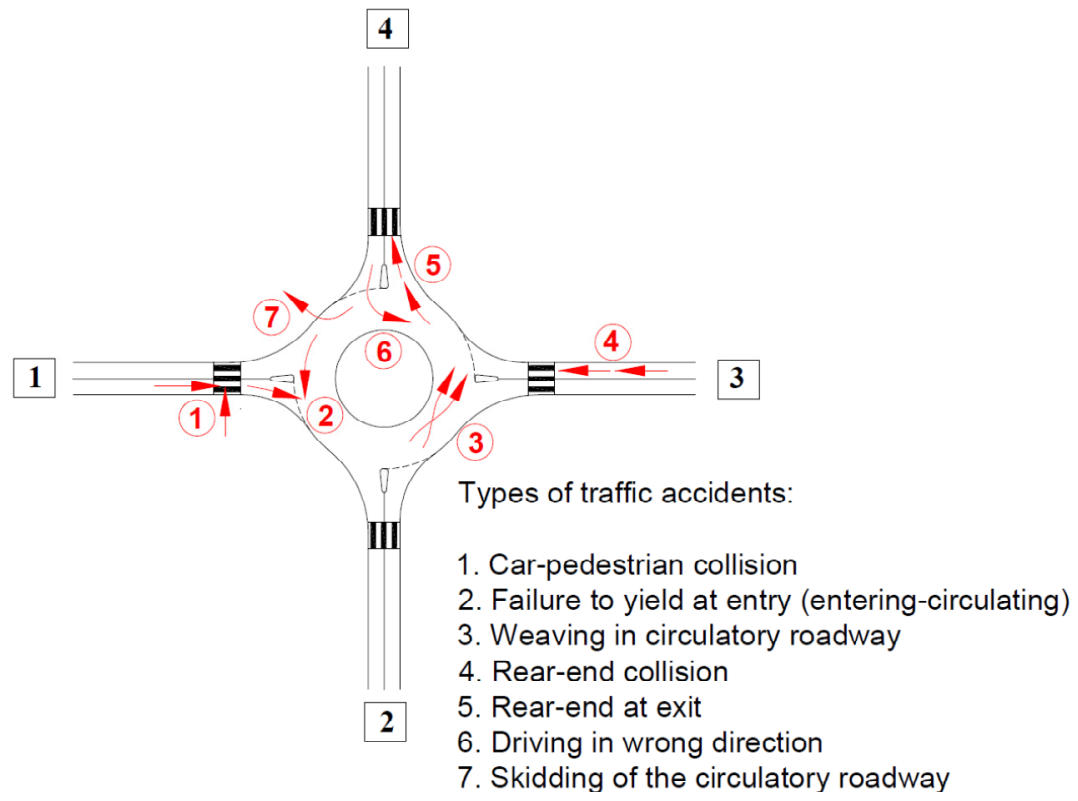

Figure 3: Diagram of collisions in the roundabout [1].

Other types of incidents have caused only 41 or $2.0 \%$ of accidents, in which 12 persons were injured or $6.38 \%$ of the total number of the accidents. 
Table 2: $\quad$ Number of accidents and injured according to the types of traffic accident [6].

\begin{tabular}{|c|c|c|c|c|c|c|}
\hline \multicolumn{7}{|c|}{ NUMBER OF ACCIDENTS ACCORDING TO TYPE OF ACCIDENT } \\
\hline Year & $\begin{array}{l}\text { Number } \\
\text { of } \\
\text { accident }\end{array}$ & $\begin{array}{c}2 . \\
\text { Failure to } \\
\text { yield at } \\
\text { entry }\end{array}$ & $\begin{array}{c}3 . \\
\text { Weaving in } \\
\text { circulatory } \\
\text { roadway }\end{array}$ & $\begin{array}{l}4 . \\
\text { Rear-end } \\
\text { collision }\end{array}$ & $\begin{array}{c}6 . \\
\text { Driving } \\
\text { in wrong } \\
\text { direction }\end{array}$ & $\begin{array}{c}7 . \\
\text { Skidding } \\
\text { of the } \\
\text { circulatory } \\
\text { roadway }\end{array}$ \\
\hline 2001 & 349 & 49 & 26 & 269 & 0 & 5 \\
\hline 2002 & 313 & 52 & 20 & 234 & 0 & 7 \\
\hline 2003 & 354 & 106 & 26 & 206 & 0 & 10 \\
\hline 2004 & 248 & 37 & 24 & 179 & 0 & 5 \\
\hline 2005 & 136 & 48 & 12 & 67 & 0 & 6 \\
\hline 2006 & 129 & 48 & 15 & 57 & 0 & 4 \\
\hline 2007 & 124 & 46 & 11 & 58 & 0 & 4 \\
\hline 2008 & 104 & 28 & 20 & 46 & 0 & 3 \\
\hline 2009 & 119 & 49 & 13 & 44 & 4 & 2 \\
\hline 2010 & 84 & 43 & 8 & 25 & 2 & 1 \\
\hline Sum & 1960 & 506 & 175 & 1185 & 6 & 47 \\
\hline \multicolumn{2}{|c|}{ Percentage [\%] } & 25.8 & 8.9 & 60.4 & 0.3 & 2.3 \\
\hline \multicolumn{7}{|c|}{$\begin{array}{l}\text { NUMBER OF INJURED ACCORDING } \\
\text { TO THE TYPES OF ACCIDENT }\end{array}$} \\
\hline Year & $\begin{array}{l}\text { Number } \\
\text { of } \\
\text { accident }\end{array}$ & $\begin{array}{c}2 . \\
\text { Failure to } \\
\text { yield at } \\
\text { entry }\end{array}$ & $\begin{array}{c}3 . \\
\text { Weaving in } \\
\text { circulatory } \\
\text { roadway }\end{array}$ & $\begin{array}{l}4 . \\
\text { Rear-end } \\
\text { collision }\end{array}$ & $\begin{array}{c}6 . \\
\text { Driving } \\
\text { in wrong } \\
\text { direction }\end{array}$ & $\begin{array}{c}7 . \\
\text { Skidding } \\
\text { of the } \\
\text { circulatory } \\
\text { roadway }\end{array}$ \\
\hline 2001 & 26 & 4 & 0 & 20 & 0 & 2 \\
\hline 2002 & 11 & 3 & 0 & 6 & 0 & 0 \\
\hline 2003 & 29 & 6 & 2 & 15 & 0 & 5 \\
\hline 2004 & 18 & 4 & 1 & 11 & 1 & 1 \\
\hline 2005 & 13 & 2 & 1 & 5 & 0 & 3 \\
\hline 2006 & 22 & 2 & 0 & 17 & 0 & 2 \\
\hline 2007 & 19 & 3 & 0 & 11 & 0 & 2 \\
\hline 2008 & 14 & 2 & 0 & 11 & 0 & 0 \\
\hline 2009 & 23 & 6 & 1 & 12 & 1 & 1 \\
\hline 2010 & 13 & 7 & 2 & 3 & 0 & 1 \\
\hline Sum & 188 & 39 & 7 & 111 & 2 & 17 \\
\hline \multicolumn{2}{|c|}{ Percentage $[\%]$} & 20.7 & 3.7 & 59.0 & 1.0 & 9.0 \\
\hline
\end{tabular}




\section{Reconstruction proposal}

\subsection{Variant 1/Nikola Šubić [7]}

Nikola Šubić, working on his Diploma Thesis in 2006 proposed a solution for the reconstruction of the respective roundabout. The proposal consists of two steps (RI, RII) which have the purpose of improving the safety by eliminating the external lane in the circular carriageway, by verticalisation of all approaches and by segregating of the right-turners from every approach, and to increase the roundabout capacity by constructing an overpass from the East-West direction and vice versa. Step RI - spatial and traffic improvement of the current condition in the sense of: approach verticalisation, channelling of vehicles, elimination of the external lane (two lanes in the circular carriageway to reduce the conflicting situations and because of the usage level of the internal marginal lane). This is to achieve spatial - time distances between approaches, adding one more lane for right turns because of increased traffic intensity of right-turners at approaches East 3 and North 4. Step RII - follow-up of step RI regarding the construction of the overpass in the East-West and West-East direction, with grade difference from the current condition in the inter-phase by $5.50[\mathrm{~m}]$ and the length of approach ramps of $180-200[\mathrm{~m}]$ to overcome the climb of $4 \%$ and extension regarding widening of the approaches West 1 and East 3 due to the construction of the overpass (Figure 4) [7].

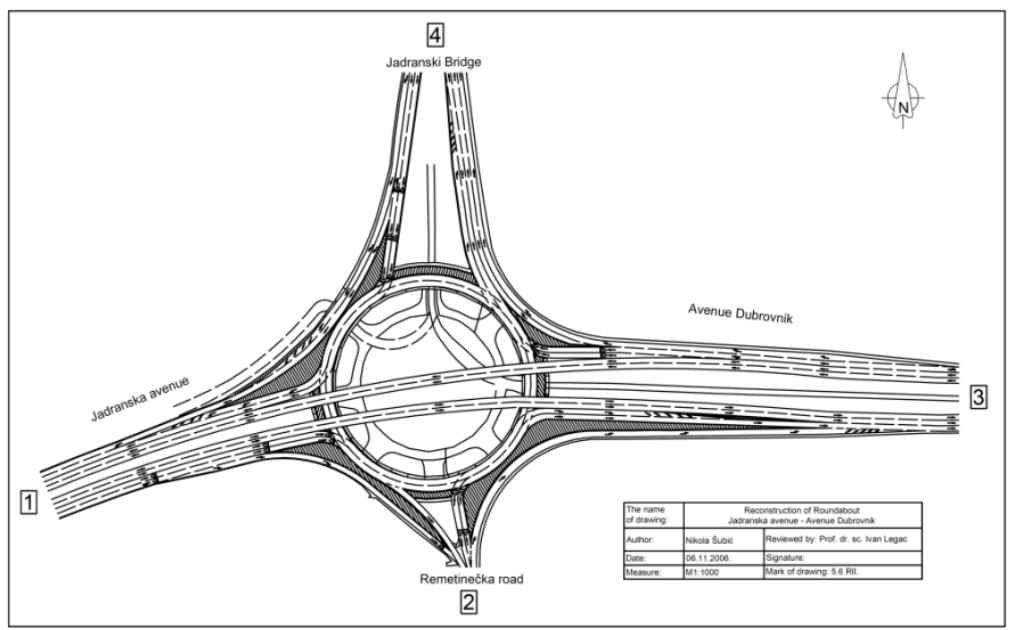

Figure 4: $\quad$ Layout of Variant 1 according to [7].

\subsection{Variant 2 - 5/Faculty of Civil Engineering and AKING [4]}

The Faculty of Civil Engineering, University of Zagreb and the business association AKING d.o.o. made in 2008 a study for the reconstruction proposal of the intersection Jadranska Avenue and Avenue Dubrovnik. For the realisation 
of the project four variants of the conceptual solutions were developed. The variant solutions are briefly described here:

- Variant 2 traffic flows West - East are guided over viaducts at +2 level

- Variant 3 traffic flows West - East are guided through tunnels at -1 level

- Varjant 4 traffic flow West - North is guided over viaduct at +2 level, traffic flow North - East is guided through the tunnels at -1 level

- Variant 5 traffic flow North - East is guided through tunnel at -1 level [4].

Based on the analysis of the financial aspects of construction, space occupancy and capacity increase, as optimal solution Variant 3 (Figure 5) was selected [4]. Apart from the construction of a tunnel at the level -1 Variant 3 proposes the keeping of three lanes in the circular carriageway, introducing traffic lights at the basic roundabout, and on all approaches the tangential segregation of the right turners that has already been achieved by the installation of grade separators in 2001 [4].

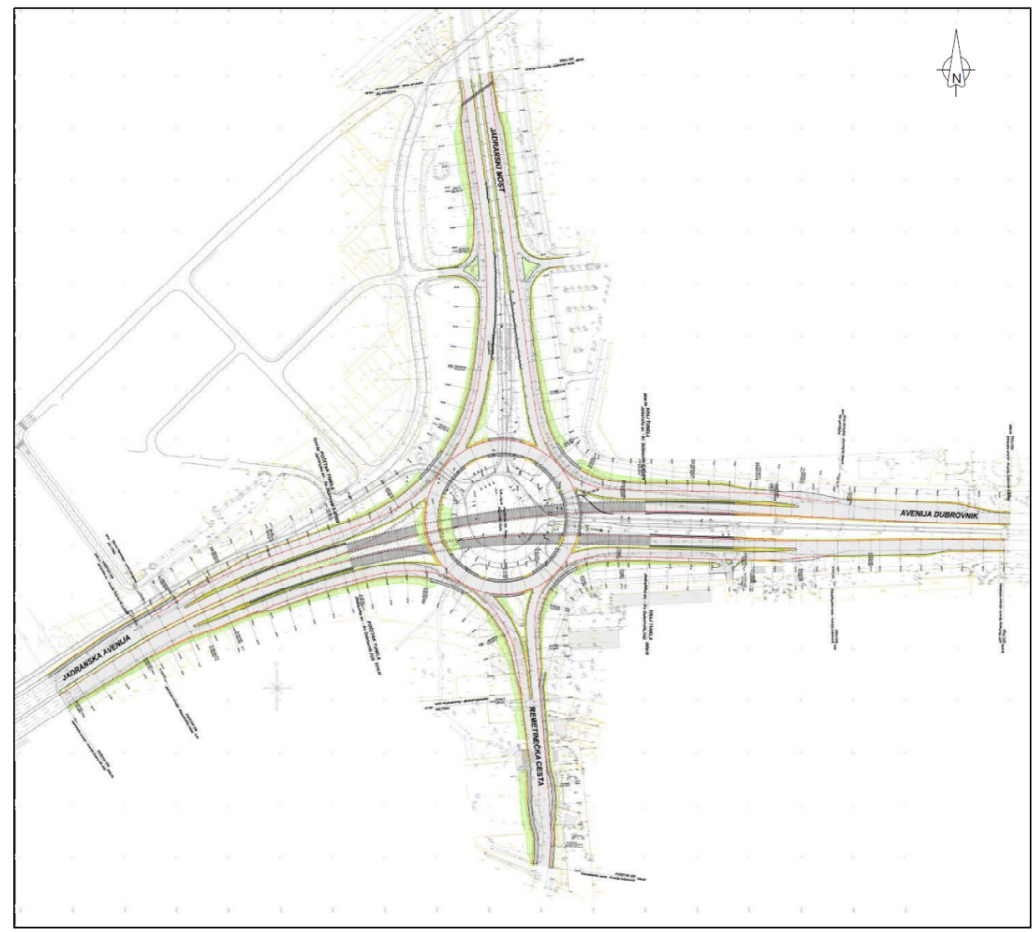

Figure 5: $\quad$ Layout of Variant 3 from the study of solution selection [4].

\subsection{Variant 6/Matko Vukušić [8]}

Working on his Final Thesis in 2011 Matko Vukušić proposed a solution for the reconstruction of the respective intersection (Figure 6). The proposal consists of Phase I and Phase II. In Phase I of the reconstruction the approaches are 
verticalised, right turners are channelled at all approaches except for the approach Jadranska Avenue, the northern and southern carriageways of Jadranska Avenue are spaced out, and the number of lanes on its southern part is reduced (from three to two), in order to prepare it for the digging of the tunnel in the next phase. The approaches to the roundabout are designed with radius $\mathrm{R}=$ $20[\mathrm{~m}]$ to enable merging of the cargo vehicles. Furthermore, the number of traffic lanes in the roundabout is reduced in order to increase the traffic flow safety in the roundabout. The right turners are physically segregated at all approaches except the western one 1 , and because of the increased intensity one traffic lane each is added to the northern 4 and eastern 3 approach. The second phase of reconstruction consists of the construction of two tunnel pipes in the East-West and West-East direction (Jadranska Avenue - Avenue Dubrovnik), and the construction of the overpass from the North towards the East (Jadranski Bridge - Avenue Dubrovnik). The length of the ramps for descending (entry) into the tunnels and climbing (exit) from the tunnels is about 150 metres with a decline of $4 \%$. The tunnels are located at 5.5 metres below the level of the trams that pass below the roundabout. The overpass is constructed from the approaching and exiting ramps with a gradient of $4 \%$ that are about 150 metres long and a horizontal section which is elevated 5.5 metres above the roundabout carriageway. For easier merging of the vehicle from the overpass from the North, those from the tunnel from the West, and the segregated right turners from the South to the Avenue Dubrovnik the eastern exit from the roundabout, which is not required any more, is closed [8].

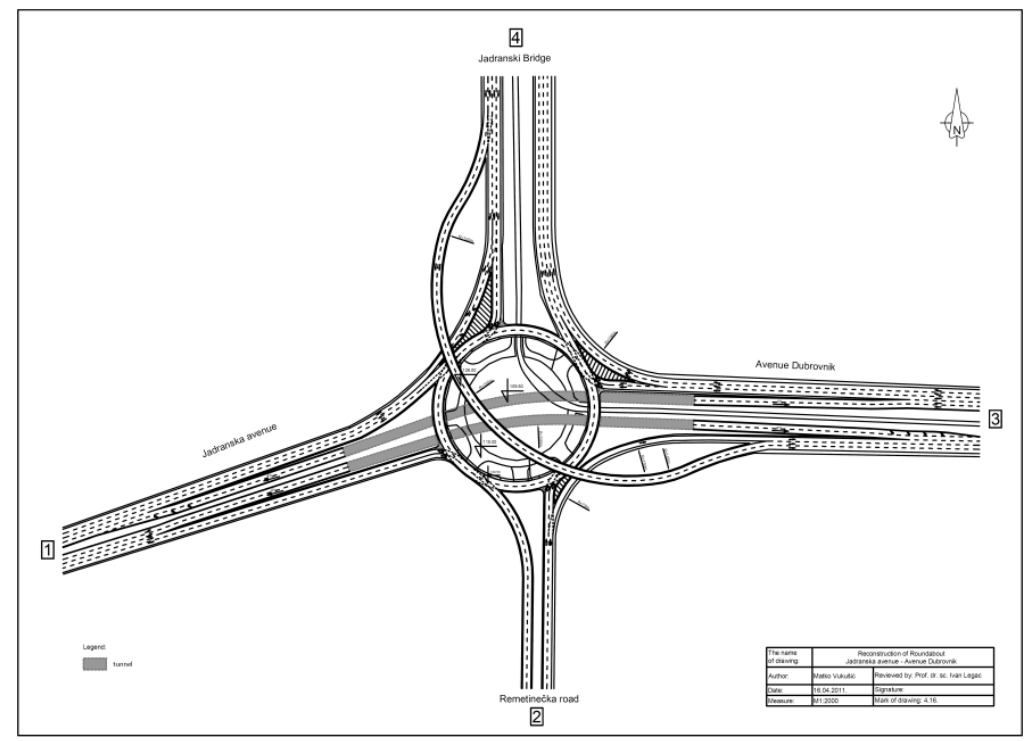

Figure 6: $\quad$ Layout of Variant 6 according to [8]. 


\section{Results of multi-criteria evaluation and selection of the optimal solution}

The AHP (Analytic Hierarchy Process) method was selected for multi-criteria decision-making because in the concrete case a larger number of criteria and decision-makers is considered. The basic elements of the hierarchical structure in case of AHP model are the function of objective, alternatives (variants), criteria and subcriteria $[9,10]$. The hierarchical structure of the multi-criteria analysis model in the function of project selection is presented schematically in Figure 7. The result of applying the multi-criteria analysis is the determination of the best variant for the reconstruction of the Jadranska Avenue and Avenue Dubrovnik. Since the function of objective, alternatives and criteria have already been defined, the procedure of determining the best variant means:

- defining of relative importance of criteria in relation to the research objective, i.e. criteria ranking (comparison of relative importance of criteria regarding all criteria pairs (Saaty scale), calculation of the criteria weights),

- ranking of certain variants/alternatives regarding a single criterion, i.e. calculation of the values of alternatives according to criteria,

- calculation of the total priority for each variant/alternative, selection of the best variant/alternative [9].

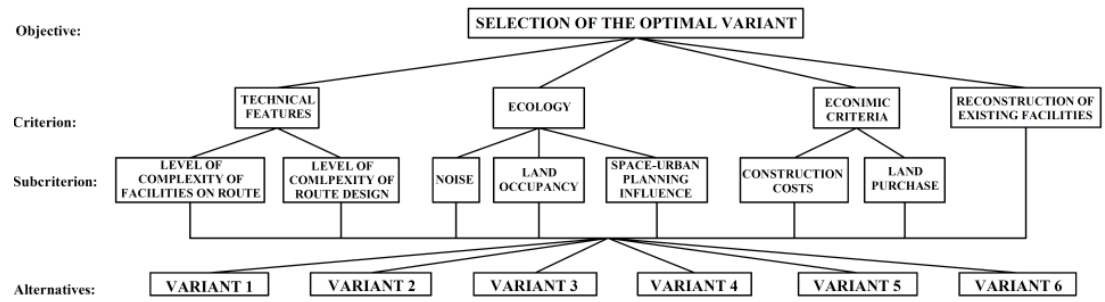

Figure 7: Schematic presentation of the hierarchic structure of the multicriteria analysis model [11].

In solving the subject of multi-criteria analysis the software package Expert Choice presented in Figure 8 was used. Since the role of measures/criteria is to describe the alternatives in such a way that it is possible for two alternatives to clearly determine which is more suitable regarding the considered criterion, the following criteria and subcriteria have been selected (Figure 9):

- Technical features: level of complexity of the facilities on the route, level of complexity of the route design;

- Ecology: noise, land occupancy, spatial and urban planning influence;

- Economic criterion: construction cost, land purchase;

- Reconstruction of the existing facilities [11]. 


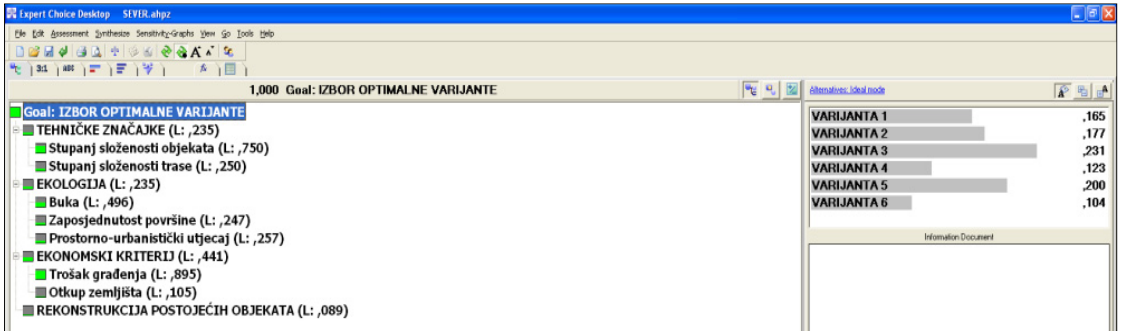

Figure 8: Presentation of alternatives, criteria, and subcriteria using expert choice software package [11].

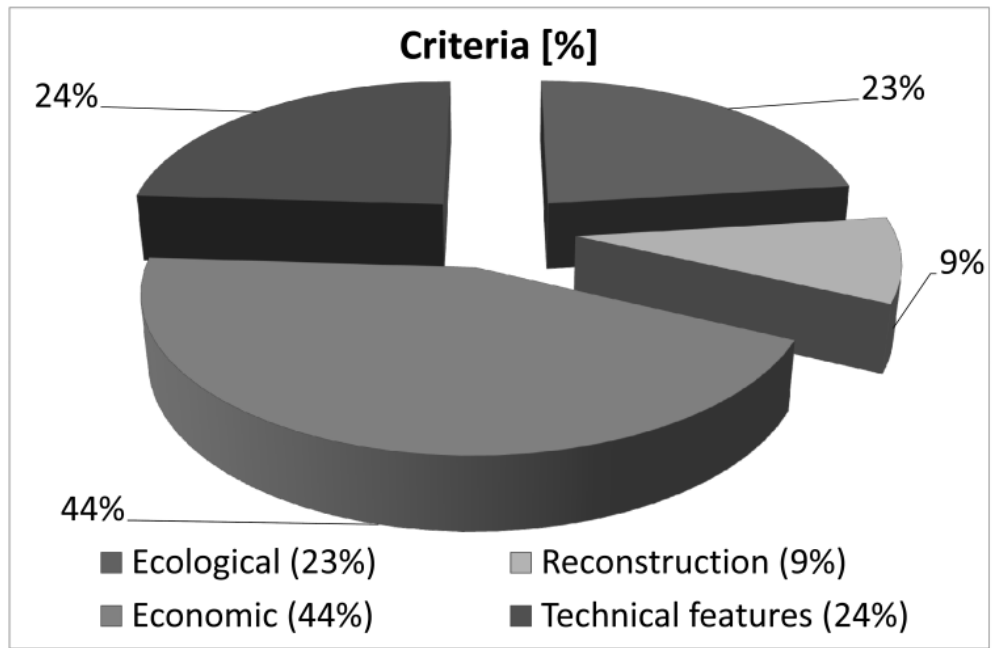

Figure 9: Criteria in relation to the function of objective.

In determining the weights of the criteria more complex methods have been developed, and also the assessments of the decision-makers are important, regarding the knowledge about the problems and the experience.

By applying the AHP method and the simulation in software package Expert Choice with the aim of selecting the optimal reconstruction variant of the Jadranska Avenue and Avenue Dubrovnik intersection the result has been obtained according to which the best variant is Variant 3 (weight 0.231) Figure 10. 


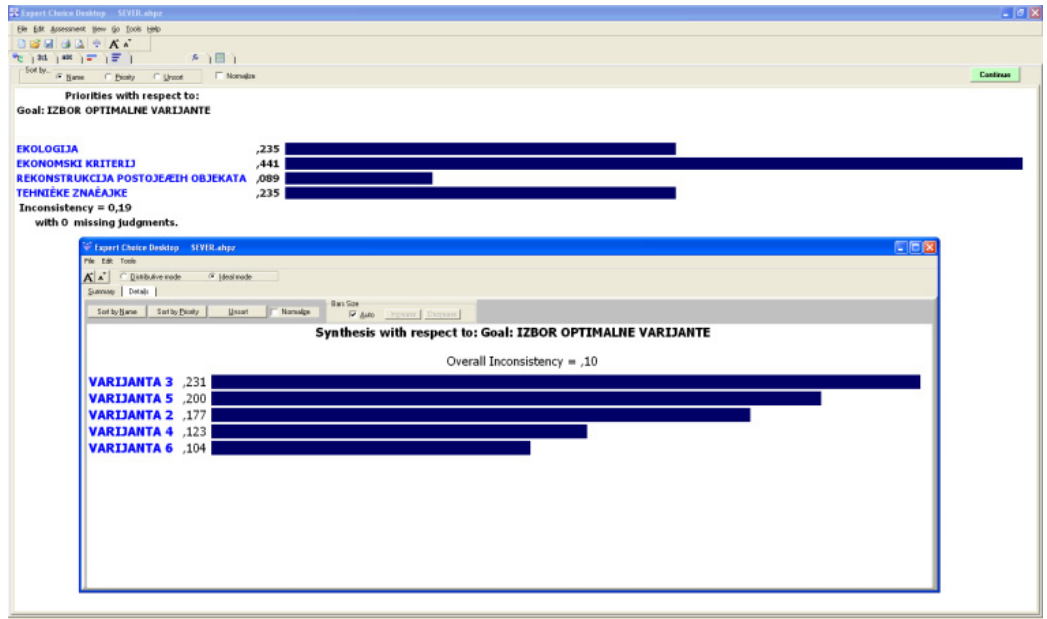

Figure 10: Presentation of the obtained results for the selection of variants using Expert Choice [11].

\section{Conclusion}

Multiple checks of the traffic serviceability of a big roundabout at the periphery of the City of Zagreb confirm that its radical reconstruction is necessary in the near future. For this purpose several analyses of the traffic flows have been carried out, with special emphasis on the traffic capacity and safety components, and on their corrections with the design specifics of the intersection.

Consequently to the performed traffic and urban planning analyses certain solutions of the roundabout reconstruction have been developed. For objective selection of the optimal solution multi-criteria decision-making was carried out using AHP (Analytic Hierarchy Process) method. In solving the multi-criteria analysis procedure the software package Expert Choice was used with precisely defined criteria and subcriteria. By using the AHP method and simulation in the software package Expert Choice the obtained result showed that the most suitable is Variant 3 for the reconstruction of the Jadranska Avenue - Avenue Dubrovnik roundabout in Zagreb. It should be noted that for the final analyses and the selection of the optimal solution the objective weights/ponders of the basic criteria should be objectivised and the equality of the processing of the considered versions of reconstructing the respective intersection should be insured.

\section{References}

[1] Korelacija oblikovnosti i sigurnosti u raskrižjima s kružnim tokom prometa (leader I. Legac), Faculty of Transport and Traffic Sciences, Zagreb, 20082011. 
[2] Legac, I., Pilko, H., Šubić, N., Analysis of traffic safety on roundabout Jadranska Avenue - Avenue Dubrovnik in Zagreb. Conference proceedings Transport, Maritime and Logistics Science, 14th ICTS 2011, Portorož, Slovenia, p. 11, 27 May, 2011.

[3] Prometna analiza i unapređenje sigurnosti i protočnosti raskrižja s kružnim tokom prometa, studija (leader I. Legac), Faculty of Transport and Traffic Sciences, Zagreb, pp. 28-136, October 2009.

[4] Faculty of Civil Engineering and AKING d.o.o., Rekonstrukcija raskrižja Jadranske i Dubrovačke avenije - Studija izbora rješenja, Faculty of Civil Engineering and AKING d.o.o., Zagreb, pp. 1-13, 2008.

[5] Legac, I., Pilko, H., Šubić, N., Introduction of Roundabouts in Croatia preliminary experiences. Proceedings on 16th IRF World Congress, Lisboa, p. 9, $25-28$ May, 2010.

[6] Ministarstvo unutarnjih poslova: Analiza stanja sigurnosti u prometu na raskrižju Jadranska avenue - Jadranski Bridge - Remetinečka Road Avenue Dubrovnik, Zagreb, 2010.

[7] Šubić, N., Prijedlog rekonstrukcije i prijedlog sigurnosne optimizacije kružnog raskrižja Avenue Dubrovnik - Remetinečka Road u Zagrebu (mentor I. Legac), Faculty of Transport and Traffic Sciences, Zagreb, pp. 49-63, 2007.

[8] Vukušić, M., Prijedlog rješenja raskrižja Remetinečke ceste i Jadranske avenije u Zagrebu, Final thesis (mentor I. Legac), Faculty of Transport and Traffic Sciences, Zagreb, pp. 46-55, 2011.

[9] Barić, D., Čurepić, D., Radačić, Ž., Implementation of relevant methods in assessing traffic-technological projects. Promet - Traffic \& Transportation, 19(5), pp. 329-336, 2007.

[10] Barić, D., Metode za ocjenu i izbor investicijskih projekata u prometu, Master thesis, Faculty of Transport and Traffic Sciences, Zagreb, pp. 4055, 75-85, 107-115, 2006.

[11] Sever, K., Prijedlog rekonstrukcije raskrižja Jadranske avenije i Avenije Dubrovnik u Zagrebu, Diploma paper (mentor I. Legac), Tehničko veleučilište u Zagrebu, Zagreb, pp. 72-76, February 2012. 